\title{
Current trend of maternal health in Indonesia
}

\author{
Noviyani Sugiarto, Doddy A. Kumboyo
}

Faculty of Medicine, Universitas Mataram, Mataram, West Nusa Tenggara, Indonesia

\begin{abstract}
Abstrak
Latar belakang: Pencapaian Millenium Development Goals (MDGs) akan mendapat penilaian dalam tiga tahun mendatang (2015). Beberapa parameter dari bidang kesehatan ibu dievaluasi secara berkesinambungan. Tujuan makalah ini adalah untuk melaporkan pencapaian kesehatan ibu yang diperoleh Indonesia berdasarkan data Riset Kesehatan Dasar (Riskesdas) 2010.
\end{abstract}

Metode: Penggunaan data tersier dari Riskesdas terbaru (tahun 2010).

Hasil: Hasil yang didapatkan berupa data perkawinan, reproduksi, abortus, akses ibu hamil ke pelayanan kesehatan, tempat persalinan, penolong persalinan, dan masa nifas.

Kesimpulan: Informasi terbaru menyatakan adanya peningkatan pencapaian di bidang kesehatan ibu, namun tetap diperlukan upaya keras dalam mempertahankan dan meningkatkan pencapaian tersebut. Evaluasi berkesinambungan diperlukan untuk meningkatkan pencapaian ini. (Med J Indones. 2012;21:179-83)

\begin{abstract}
Background: Achievement of Millennium Development Goals (MDGs) will be assessed in the next three years (2015). Several parameters in the area of maternal health are evaluated continuously. The aim of this paper is to formally summarize and report the state of maternal health in Indonesia based on the data from Basic Health Survey (Riskesdas) 2010.

Methods: This paper utilizes tertiary data obtained from the latest Riskesdas (2010).

Results: Data that is available in the report covers data about marriage, reproduction health, abortion, access to health care for pregnancies, place of labor, health care provider, as well as rate of the first postpartum period visit.

Conclusion: The latest data shows improvement in the maternal health area, nevertheless large effort in maintaining and improving the condition is still needed. Continuous evaluation is also proven to be essential in achieving the goals. (Med J Indones. 2012;21:179-83)
\end{abstract}

Keywords: Indonesia, maternal health, millennium development goals

One of important achievement which is targeted in Millennium Development Goals 2015 is the decrease of maternal and neonatal mortality. ${ }^{1}$ In general, maternal health have become a priority in MDGs, decanted as the fifth item (MDGs 5), that is to "improve quality of maternal health"., ${ }^{2,3}$ In the April 2011 report, Hernawati et $\mathrm{al}^{4}$ from Directorate of Maternal Health Ministry of Health Republic of Indonesia, mentioned that maternal mortality in Indonesia, based on Basic Health Survey called "Riskesdas" latest data on 2007, was 228 per 100.000 live births. Though we have succeeded to reduce the number as compared to the basic data (baseline) of 1991, which reported 390 per 100.000 live births, this number is still far from MDGs 2015 goals that expect maternal mortality of 102 per 100.000 live births. Hernawati concluded that we must continue our hard work in order to achieve the target. ${ }^{4}$

Maternal mortality is just the end of a lengthy process. ${ }^{5,6}$ Moeloek $^{7}$ coined the term "Road map to die" for pregnant mothers in Indonesia. The process started since adolescence with the existence of premarital sexual behavior and in some cases involves illegal abortion. Most cases also have low access to healthcare and experience less than adequate pregnancy, labor, and postpartum care. Each parameter mentioned above has impact on the rate of maternal mortality. In her presentation, Hernawati mentioned that the training of health care providers, acceleration in the usage of contraception, as well as improvement in service coverage of antenatal care and care for failure cases of family planning program (unmeet need), has been put in place in order to achieve the goals in $2015 .^{4}$

This article will show several relevant parameters related to maternal mortality in Indonesia. Information that exists in this manuscript is obtained from the latest Riskesdas (2010). ${ }^{8}$ This national information must be published in scientific and popular magazines in order to be socialized among scientists and clinicians who work in health cares and academic institutions.

\section{METHODS}

This article use tertiary data from Basic Health Survey "Riskesdas" 2010, Ministry of Health Republic of Indonesia and presentation material from Directorate of Maternal Health, Ministry of Health Republic of 
Indonesia. Riskesdas 2010 is the latest national health survey in Indonesia which contain only for maternal and child health, infectious diseases, and health behaviour in all Indonesian population (33 provinces). We divide maternal health concern in this census to two classification; marriage, reproduction, and abortion status and pregnancy and labor.

\section{RESULTS}

\section{Marriage, reproduction, and abortion}

Age of first marriage of women in Indonesia can be considered very early. Based on comparison of urban and rural data, rate of early marriage was higher in rural area $(6.2 \%)$, non-educated women $(9.5 \%)$, farmers, fishermen, and laborer (6.3\%), as well as women of low socio-economic level/ $1^{\text {st }}$ quintile $(6 \%)$. Figure 1 shows distribution by age of the first marriage of women in Indonesia.

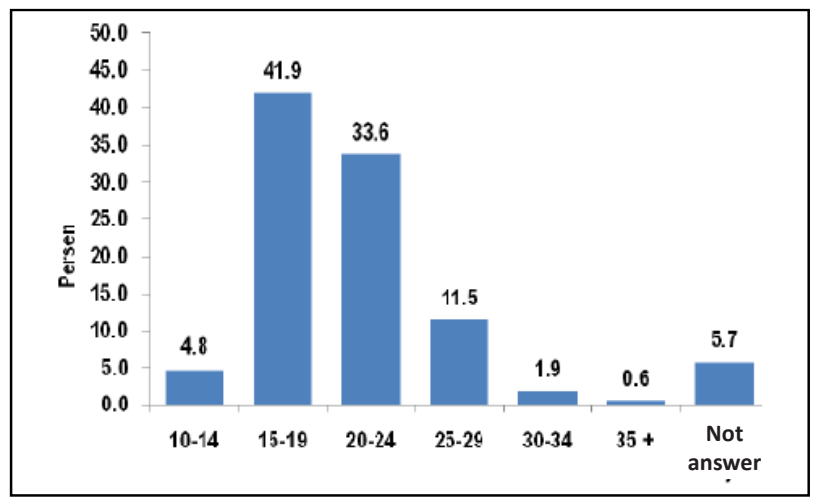

Figure 1. First marriage age of women in Indonesia (Cited from Basic Health Survey, Ministry of Health Republic of Indonesia)
Early menstruation and marriage age results in wider span of reproduction age of Indonesian women and in turn causes more children to be born. Rate of pregnancy on the age of $10-14$ was $0.01 \%, 1.9 \%$ on the age of $15-$ 19 , and $6 \%$ on the age of $20-24$ as well as $25-29$. On national level, there were $8.4 \%$ of women in Indonesia who had born 5-6 children and 3.4\% of women who had born more than 7 children. Province with highest number of women with most number of children born (more than 7 children) was West Papua (7.5\%), and the lowest was D. I. Yogyakarta (0.5\%).

The usage of contraception is very important based on the above condition. Generally, the usage of modern contraception was done by $57.4 \%$ (2007) and $55.85 \%$ (2010). From the goal of $65 \%$ in 2015, it seems that Indonesia will attain success at this category. Unfortunately, based on this data, only $25.9 \%$ of woman on the age of 10-14 use contraception. This condition requires more attention because pregnancy at the early age means higher risk of maternal and baby death. Comparing data from 2007 and 2010, there was a slight reduction in usage of contraception for Indonesian women.

Premarital sexual behavior is also a big problem at this time. In Indonesia, although the number of premarital sexual of teenage men and women is under 5\% (still lower compared to western countries), this number will cause increase in the number illegal abortion which is very dangerous. The rate of abortion of women at the age of 10-59 was 3.5\%. Till now, Indonesian traditional drink (called "jamu") and pills are still the most common way to perform abortion, while curettage is selected mostly only in the case of miscarriage.

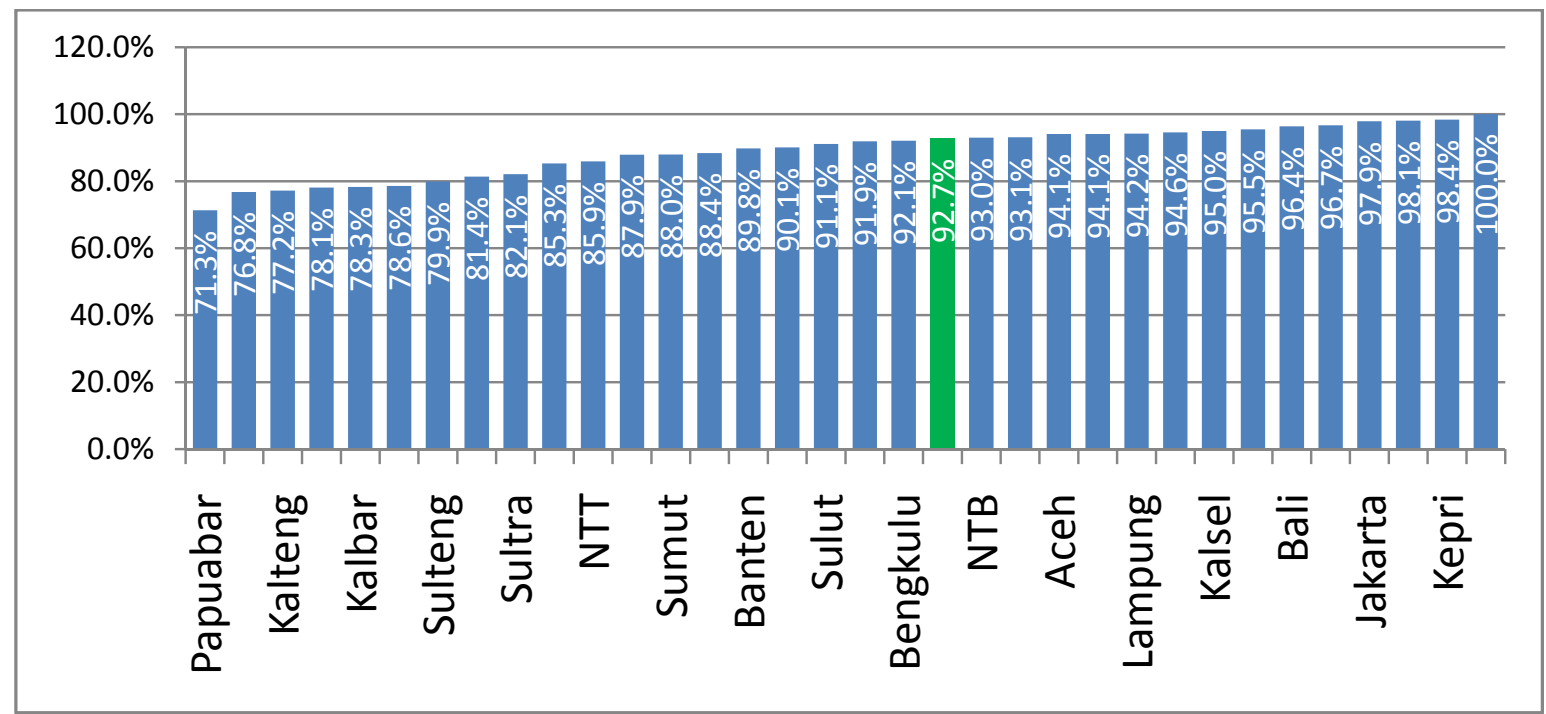

Figure 2.K1 antenatal service coverage (Riskesdas 2010). Green color is Indonesia national average (Cited from Hernawati, et al. Ministry of Health Republic of Indonesia) 


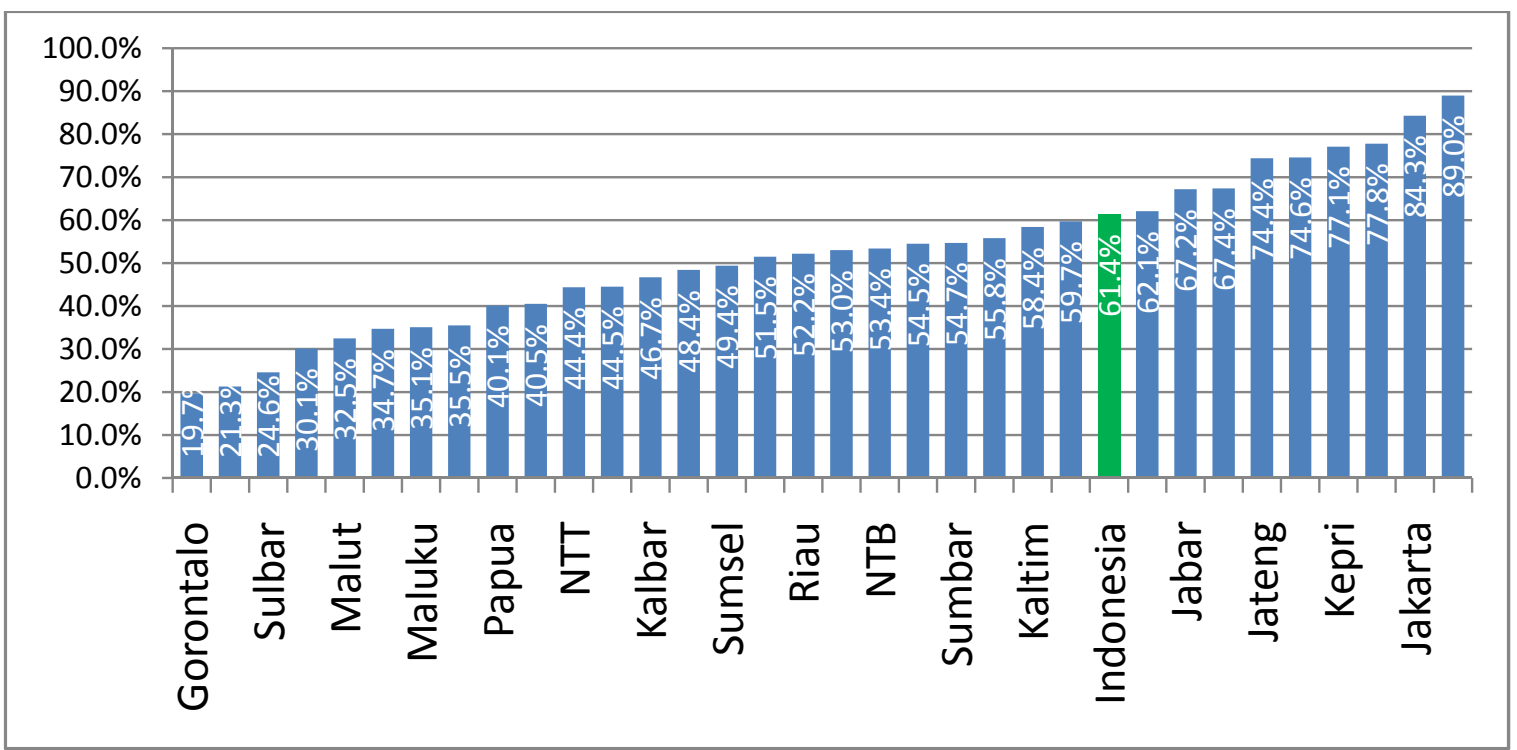

Figure 3.K4 antenatal service coverage (Riskesdas 2010). Green colour is Indonesia national average (Cited from Hernawati, et al. Ministry of Health Republic of Indonesia)

\section{Pregnancy and labor}

Pregnancy and labor are two factors that are directly related to maternal mortality. From all women married by the age of 10-59 in Indonesia, reporting of pregnancy for examination by health care providers were only performed by $83.3 \%$. Six percent of pregnant women never checked their pregnancy at all, while 3.2\% checked their pregnancy with midwifes. Health care providers who examine pregnancy consists of midwifes (71.4\%), obstetricians and gynecologists (19.7\%), and general practitioners $(1.7 \%)$.

On national level, the average for single pregnancy visit (K1) is $92.7 \%$. Eight provinces have reached MDGs goals 2015 (>95\%) (Figure 2). Meanwhile, the rate for four times pregnancy visit (K4) was only $61.4 \%$ (still far from MDGs goals 90\%). At present time, there is no province that reaches the MDGs goals. D. I. Yogyakarta was the province which has top $\mathrm{K} 4$ antenatal service coverage (89\%) (Figure 3).

\section{DISCUSSION}

Data will become useful if publicized widely. Although the data only obtained and cited from report of basic health survey, the information that is given in this manuscript can encourage further observation and program evaluation in each areas as well as become a reference for other studies or reviews.

This report informs us that there has been improvement in the field of maternal health in Indonesia in various aspects. However, to decrease maternal mortality

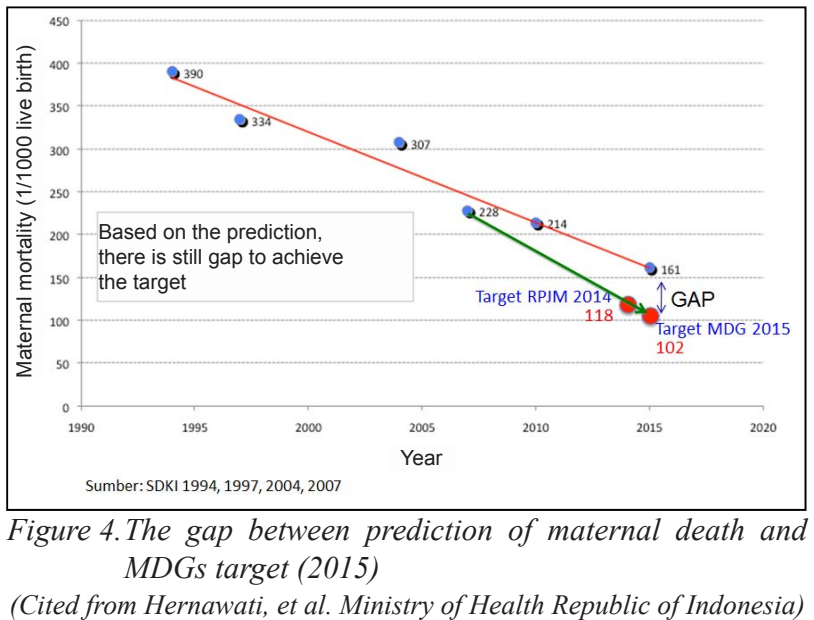

in order to achieve target in MDGs 2015 (102 per 100.000 live births), we need to work extra hard. Ministry of Health has specified the targets and predictions (Figure 4). All in all, this requires multidisciplinary approach, covering economy, social, even strong political support from local government. This has been proven by D. I. Yogyakarta which has become the "champion" in all aspects.

The rate of support during labor from health care providers in Indonesia was as high as $82.2 \%$ of pregnancies. This number will continue to increase, as compared to survey done in 2007 which showed rate of $75.4 \%$. Nevertheless, there was a wide gap between urban $(91.4 \%)$ and rural $(72.5 \%)$ area in term of this factor. On province level, D. I. Yogyakarta occupied the best rank in the case of percentage of labor support by health care providers $(98.6 \%)$. The province 
with lowest rate was North Moluccas $(26.6 \%)$. This difference showed that the rate of labor support had not been distributed equally.

In terms of location of labor, 55.4\% labor performed in healthcare facilities, while $43.2 \%$ performed at home. For those labor performed at home, $51.9 \%$ were helped by midwife while the rest were helped by traditional midwife (called "dukun beranak"). Highest percentage of labor in healthcare facilities was obtained (again) by D. I. Yogyakarta $(94.5 \%)$, while the lowest was obtained by Southeast Sulawesi (8.7\%). This difference was caused by distribution of residential area (urban versus rural) and socio-economic level.

D. I. Yogyakarta achievement can also be seen in the rate of first postpartum visit which is $53.1 \%$ higher compared to other provinces. In general, the rate of first postpartum visit within 0-1 day was 32.6\% for mothers in urban area and 29,9\% in rural area. Unfortunately, there were $20.5 \%$ of mothers in urban area and $31,8 \%$ in rural area who never get postpartum visit at all.

Health care providers who assist the labor and place of labor are assumed all-time to be related to maternal death. This is based on epidemiologic studies about causes of maternal death which must be solve by health care professionals, such as general physicians and midwives. But, it's remain controversial based on Ronsmans's ${ }^{9}$ study. Ronsmans et al found in his research that only $33 \%$ of women in two districts in Indonesia gave birth with assistance from a health professional, and among them, mortality was extremely high for those from low socio-economic level, but there is still very high in middle level.

This result similar with Indonesian data. Hernawati et al in her presentation stated that " $50 \%$ maternal death in Indonesia not occur in provinces with low access to health care providers". Hernawati also found the correlation is week between the two factors $(\mathrm{r}=0.45)$, also the correlation between maternal death and number of midwives $(r=0.3)$. Based on the data, we must consider other factors contribute to maternal death.

Mumtaz et $\mathrm{al}^{6}$ stated that health system as social institution play an important role for all maternal health program in country. Role of health system as social institution seems to be a new perspective in our program. In the old paradigm, human resources is the most important substance, but when we have strengthen our system, we can lesser the role of human resources. For Indonesian, we must build strong referral system (and transportation) in rural areas so maternal death in rural and remote areas can be reduced.

One of the most important weakness of Riskesdas 2010 is does not stated about the cause of maternal death related with pregnancy and labor. It seems that haemorrhage and hypertensive disorder still the top cause of maternal mortality in Indonesia, the same as other developing countries as stated in systematic review by World Health Organization. ${ }^{10}$ We suggest upcoming national health survey include the cause of maternal death in Indonesian population.

Information above still requires further analysis to see the correlation in general among different aspects of maternal health. Hernawati et $\mathrm{al}^{3}$ has presented some of this inter-variable correlation and analysis to the Ministry of Health Republic of Indonesia. To achieve MDGs goals, overall effort in reducing maternal mortality in Indonesia is required. The time has come for Indonesia to reach for these goals, for the benefit of the people and to achieve prosperity in general, and also to attain World Health Organization standard in terms of health status.

\section{Acknowledgement}

We thank Basic Health Survey Ministry of Health Republic of Indonesia for the data and also Ina Hernawati, MD, MPH from the Directorate of Maternal Health Ministry of Health Republic of Indonesia for her presentation that we use as the source of data and figures which we use in this article.

\section{REFERENCES}

1. Bustreo F, Requejo JH, Merialdi M, Presern C, Songane F. From safe motherhood, newborn, and child survival partnerships to the continuum of care and accountability: moving fast forward to 2015. Int J Gynaecol Obstet. 2012 Aug 8 [Epub ahead of print].

2. World Health Organization. Millennium development goals. WHO; 2000.

3. United Nation. Millenium development goals at a glance. UN; 2010.

4. Hernawati I. Analisis kematian ibu di Indonesia tahun 2010. Pertemuan Teknis Kesehatan Ibu; Bandung, 6 Apr 2011 .Indonesian.

5. Esscher A, Haglund B, Hogberg U, Essen B. Excess mortality in women of reproductive age from low-income countries: a Swedish national register study. Eur J Public Health. 2012 Jul 31 [Epub ahead of print].

6. Mumtaz Z, Salway S, Shanner L, Zaman S, Laing L. Addressing disparities in maternal health care in Pakistan: gender, class, and exclusion. BMC Pregnancy Childbirth. 2012;12(1):80.

7. Moeloek FA. Roadmap to die. Lecture at Department of Obstetrics and Gynecology, Faculty of Medicine Universitas Indonesia; 2009. 
8. Badan Penelitian dan Pengembangan Kesehatan. Riset kesehatan dasar 2010. Jakarta: Departemen Kesehatan Republik Indonesia; 2011 .Indonesian.

9. Ronsmans C, Scott S, Qomariyah SN, Achadi E, Brauholtz $\mathrm{D}$, Marshall $\mathrm{T}$, et al. Professional assistance during birth and maternal mortality in two Indonesian districts. Bull World Health Organ. 2009;87:416-23.

10. Khan KS, Wojdyla D, Say L, Gulmezogly AM, Van Look PF. WHO analysis of causes of maternal death: a systematic review. Lancet. 2006;367(9516):1066-74. 